Correction

\title{
Correction: Moustafa et al. Insecticidal Activity of Lemongrass Essential Oil as an Eco-Friendly Agent against the Black Cutworm Agrotis ipsilon (Lepidoptera: Noctuidae). Insects 2021, 12,737
}

\author{
Moataz A. M. Moustafa ${ }^{1}$, Mona Awad ${ }^{1}{ }^{(D}$, Alia Amer ${ }^{2}$, Nancy N. Hassan ${ }^{1}$, El-Desoky S. Ibrahim ${ }^{1}$, \\ Hayssam M. Ali ${ }^{3}$ (D), Mohammad Akrami ${ }^{4}$ iD and Mohamed Z. M. Salem ${ }^{5, * D}$
}

check for updates

Citation: Moustafa, M.A.M.; Awad, M.; Amer, A.; Hassan, N.N.; Ibrahim, E.-D.S.; Ali, H.M.; Akrami, M.; Salem, M.Z.M. Correction: Moustafa et al. Insecticidal Activity of Lemongrass Essential Oil as an Eco-Friendly Agent against the Black Cutworm Agrotis ipsilon (Lepidoptera: Noctuidae). Insects 2021, 12, 737. Insects 2021, 12, 991. https:/ / doi.org/ $10.3390 /$ insects12110991

Received: 29 October 2021 Accepted: 30 October 2021 Published: 4 November 2021

Publisher's Note: MDPI stays neutral with regard to jurisdictional claims in published maps and institutional affiliations.

Copyright: (c) 2021 by the authors. Licensee MDPI, Basel, Switzerland. This article is an open access article distributed under the terms and conditions of the Creative Commons Attribution (CC BY) license (https:/ / creativecommons.org/licenses/by/ $4.0 /)$.
1 Department of Economic Entomology and Pesticides, Faculty of Agriculture, Cairo University, Giza 12613, Egypt; moataz.moustafa79@gmail.com (M.A.M.M.); mona.awad2003@gmail.com (M.A.); whitehorse3050@gmail.com (N.N.H.); moat_mon@yahoo.com (E.-D.S.I.)

2 Medicinal and Aromatic Plants Department, Horticulture Research Institute, Agricultural Research Center, Giza 12556,Egypt; dr_aliaamer@yahoo.com

3 Botany and Microbiology Department, College of Science, King Saud University, P.O. Box 2455, Riyadh 11451, Saudi Arabia; hayhassan@ksu.edu.sa

4 Department of Engineering, University of Exeter, Exeter EX4 4QF, UK; m.akrami@exeter.ac.uk

5 Forestry and Wood Technology Department, Faculty of Agriculture (El-Shatby), Alexandria University, Alexandria 21545, Egypt

* Correspondence: zidan_forest@yahoo.com or mohamed-salem@alexu.edu.eg

\section{Additional Affiliations}

In the published publication [1], there was an error regarding the affiliations for Hayssam M. Ali. In the original version of this article, Hayssam M. Ali was incorrectly affiliated with 'Timber Trees Research Department, Sabahia Horticulture Research Station, Horticulture Research Institute, Agriculture Research Center, Alexandria, Egypt'. This affiliation has be removed. The correct affiliation is listed below.

Botany and Microbiology Department, College of Science, King Saud University, P.O. Box 2455, Riyadh 11451, Saudi Arabia

The authors apologize for any inconvenience caused and state that the scientific conclusions are unaffected. The original publication has also been updated.

\section{Reference}

1. Moustafa, M.A.M.; Awad, M.; Amer, A.; Hassan, N.N.; Ibrahim, E.-D.S.; Ali, H.M.; Akrami, M.; Salem, M.Z.M. Insecticidal Activity of Lemongrass Essential Oil as an Eco-Friendly Agent against the Black Cutworm Agrotis ipsilon (Lepidoptera: Noctuidae). Insects 2021, 12, 737. [CrossRef] [PubMed] 